\title{
Випадок успішного консервативного лікування шлункової нориці як одного з багатьох уск.ладнень виразкової хвороби дванадцятипалої КИІии
}

\begin{abstract}
У публікації наведено клінічне спостереження одного пацієнта М. протягом останніх шести років. У 2010 р. пацієнт М., 46 років був направлений в центр гострого панкреатиту з підозрою на гострий тяжкий панкреатит, а через 12 год після госпіталізації прооперований з приводу перфоративної виразки дванадцатипалої кишки з поширеним перитонітом на тлі виразкового стенозу дванадцатипалої кишки. Виконано ушивання виразки з накладанням попереду-ободового гастроентероанастомозу. Систематичного лікування не отримував. У лютому 2016 р. госпіталізований в хірургічне відділення з флегмоною передньої черевної стінки, причиною якої була пенетрація виразки гастроентероанастомозу в передню черевну стінку. Після розкриття флегмони відкрилася шлункова нориця, яка закрилася на тлі інтенсивної протизапальної терапії і приймання максимальних доз пантапразолу.

У квітні 2016 р. виконано резекцію шлунка і гастроентероанастомоз за Ру. В подальшому було три епізоди кровотеч, які усували консервативно.

У кінці 2016 р. з'явилися труднощі при ковтанні їжі, діагностовано стеноз нижньої третини стравоходу, пройшов курс лікування в торакальному відділенні за допомогою бужування, прохідність відновлена. Повторно оглянутий в квітні 2017 р., стан задовільний, ковтання вільне. На ФГДС у ділянці гастроентероанастомозу рецидивна виразка.

Хворому запропоновано стаціонарне лікування у відділенні гастроентерології та обстеження з підозрою на синдром Золлінгера-Еллісона.
\end{abstract}

Ключові слова: ускладнена виразкова хвороба; сумкова нориця; консервативне лікування.

3 появою ефективних можливостей консервативного лікування виразкової хвороби шлунка та дванадцятипалої кишки практично зникла потреба в планових хірургічних втручаннях, але все частіше з'являються публікації про зростання ускладнень виразкової хвороби та їх пізню діагностику [1]. Спостерігається помітна розбіжність відносно вибору самого хірургічного втручання. Дзюбановський І. Я. та співавт. переконливо доводять перевагу органозберігаючих операцій з формакоекономічної точки зору та пропонують виділяти групи високого ризику, які краще оперувати до виникнення ускладнень [ 2,3$]$.

Лупальцов В. І. зазначає, що надмірно тривале, часом безуспішне консервативне лікування при неминучому в подальшому операційному втручанні пов'язане з великим ризиком для хворого. Консервативне лікування обов'язкове у хворих при гастродуоденальній виразці. Однак успіхи хірургії в лікуванні хворих свідчать, що при будьякому консервативному лікуванні повинні бути розумні строки та індивідуальний підхід. Одним із реальних шляхів поліпшення результатів лікування хворих із приводу гастродуоденальної ви- разки повинно бути своєчасне встановлення показань до планового операційного втручання, до виникнення життєво небезпечних ускладнень [4].

Наводимо власне спостереження, яке повністю підтверджує такі висновки: у одного хворого протягом декількох років спостерігалися всі характерні для виразкової хвороби дванадцятипалої кишки ускладнення.

Клінічний випадок. Хворий М., 46 р., історія хвороби № 1287/416 переведений з 7-ї міської лікарні до центру гострого панкреатиту - 8 міська клінічна лікарня м. Кривий Ріг 24.03.10 р. $з$ діагнозом гострий панкреатит. Захворів гостро близько 15 години 24.03.10 р. На момент госпіталізації скарги на гострий біль у животі, печію, слабкість. Стан середньої тяжкості. АТ - 170/80 мм рт. ст., частота пульсу 88 на хвилину. Язик вологий, живіт дещо піддутий, помірний дефанс у верхній половині, болючий в епігастрії та лівому підребер'ї. Симптом Чухрієнко позитивний, перистальтика вислуховується.

Під місцевою анестезією виконано лапароцентез, дренування черевної порожнини. Рідина по дренажу мутно-сірого кольору в невеликій 
кількості. Призначено інфузійну терапію. До ранку з'явилися симптоми подразнення очеревини. Загальний аналіз крові $\mathrm{Hb}-134$ г/л, Ер. - 4,3·109, Л $10,4 \cdot 10^{6}, \Pi-23$ \%, С - 59 \%, Лф - $16 \%$, М - 2 \%.

По дренажу з черевної порожнини рідина схожа на вміст дванадцятипалої кишки. Виникла підозра на перфорацію порожнистого органа. Хворого доставлено до операційної. Під інтубаційним наркозом виконано лапаротомію: виявлено перфорацію хронічної виразки дванадцятипалої кишки на тлі декомпенсованого стенозу, серозний поширений перитоніт. Виконано ушивання перфоративної виразки, гастроентероанастомоз (ГЕА) з браунівським співустям, санацію та дренування черевної порожнини.

Після операції госпіталізований у відділення інтенсивної терапії, розвинувся респіраторний дистрес-синдром, який успішно був усунений, хворого перевели в хірургічне відділення, з 5-ї доби - підвищення температури ввечері до $39^{\circ} \mathrm{C}$, на КТ від 12.04.10 р. післяопераційний інфільтрат під лівою часткою печінки, після зміни антибактеріальної терапії температура нормалізувалась, в задовільному стані 16.04.2010р. хворий виписаний на амбулаторне лікування з рекомендаціє подальшого лікування та нагляду у гастроентеролога.

Після виписки хворий вернувся на попереднє місце роботи автослюсаря, практично не проходив лікування до 23.11.2015 р., коли був госпіталізований у відділення гастроентерології 16 міської лікарні $з$ різким больовим синдромом. При обстеженні на ФГДС 03.02.2015 р. в ділянці гастроентероанастомозу виявлено виразковий дефект 1,5 х 2 см 3 підритими краями, дно кратера заповнено брудно-сірим фібрином з тромбованими дрібними судинами. Призначено противиразкову терапію, повторна ФГДС 12.02.2015 р. : виразка 1,5 х 2 х 0,3 см, післяопераційні лігатури, прохідність дванадцтипалої кишки збережена (ДПК) збережена.

Заключення: пептична виразка ГЕА, післяопераційні лігатури.

12.02.15 р. консультація хірурга, запропоновано лікування в спеціалізованому закладі, від якого хворий відмовився.

14.02.15 р. із діагнозом хвороби оперованого шлунка, виразки ГЕА великих розмірів, демпінг-синдромом середньої тяжкості, хронічним паренхіматозним панкреатитом, цукровим діабетом 2 типу, субкомпенсованим хворого виписали на амбулаторне лікування.

02.02.16 р. за направленням із поліклініки хворого госпіталізовано в хірургічне відділення 7 міської лікарні. Діагноз: хвороба оперовано- го шлунка. Пенетрація пептичної виразки в передню черевну стінку, інфільтрат післяопераційного рубця з абсцедуванням. IXC, дифузний кардіосклероз СН - I, цукровий діабет 2 типу.

Хворіє 4 доби. Стан середньої тяжкості. На передній черевній стінці щільний післяопераційний рубець, навколо нього більше справа інфільтрат 6-7 см з вираженим почервонінням та розм'якшення всередині. Того ж дня під місцевим знеболенням розкрито підапоневротичний гнійник, з якого виділилося до 500 мл мутної коричневої рідини з фібрином та домішками гною. Виконано бактеріологічний посів, рану санували, дренували. ФГДС 04.02.2016 р. : застійна гастропатія, стан після виконання ГЕА, ушивання перфоративної виразки ДПК, несформована зовнішня шлункова нориця.

Результат бакдослідження - Enterococcus fekalis. Призначено антибактеріальну терапію згідно 3 антибіотикограмою.

09.02.2016 р. після консультації професора Десятерика В. І. хворого переведено в 8 міську клінічну лікарню з приводу пептичної виразки з пенетрацією, яка ускладнилась флегмоною передньої черевної стінки та зовнішньою шлунковою норицею.

Скарги на біль в ділянці рани, наявність значної кількості виділень з рани, виражену слабкість, стан середньої тяжкості. АТ 140/100 мм рт. ст., пульс 80 на хвилину. Язик вологий, живіт м'який, болючий в ділянці рани. По ходу післяопераційного рубця на 8 см нижче грудини дефект шкіри та підшкірної клітковини з виділенням світлої рідини без запаху. Навколо рани, більше донизу, мацерація шкіри до 20 х 30см. Закрити норицю обтуратом не вдалося. Прийнято рішення вести рану відкритим способом, використовуючи відповідну укладку хворого на боці та активну аспірацію з нориці. Основу консервативного лікування склало призначення пантапразолу по 40 мг внутрішньовенно 2 рази на добу протягом одного тижня. Нориця затягнулася на 6-ту добу, дозу пантапразолу зменшено - 40 мл на добу. Рани на шкірі та передній черевній стінці загоїлися. В задовільному стані хворого 22.02.16 р. виписали з рекомендацією продовжити лікування у гастроентеролога.

04.03.16 р. хворий знову звертається в поліклініку зі скаргами на біль, затвердіння та почервоніння на місці післяопераційно рубця. Того ж дня хворого госпіталізовано в хірургічне відділення 7 міської лікарні. Історія хвороби № 798. Скарги на слабкість, АТ - 110/79 мм рт. ст., пульс 92 на хвилину. Місцево: післяопераційний рубець міцний, у верхній третині струп 0,7 х 0,4см, навко- 
ло до 10 см в діаметрі помірне почервоніння шкіри над інфільтратом до 5 см розміром, без ознак розм'якшення та флюактуації. Загальний аналіз крові Нв - 136 г/л, Ер - 4,5 х 109 267 тис., Л -11,6 $10^{6}$, П $-12 \%$, С - $48 \%$, Е - $1 \%$, Лф - $37 \%$, М - 2 \%, Нт - $45 \%$. Хворому призначено інфузійну терапію, гентаміцин, анальгін, димедрол, пантапразол, етамзилат, метаклопрамід місцево на інфільтрат димексид із гентаміцином.

Запальні прояви з третьої доби помітно зменшилися, загальний стан хворого поліпшився.

Враховуючи складний анамнез, 11.03.16 р. було скликано міський консиліум за участі головного хірурга Сухіної Т .В., завідувача кафедри хірургії ФПО професора Десятерика В. І., завідувача відділення гастроентерології 16 міської лікарні Агенко Л. П., завідувача 1 хірургічного відділення 16 міської лікарні Береговенка I. М., завідувача відділення 7 міської лікарні Аскерова А.А.Прийнято рішення перевести хворого у відділення гастроентерології для продовження противиразкової та протизапальної терапії та підготовки хворого до операційного лікування.

З 14.03 до 4.04.16 р. хворий проходив лікування у відділенні гастроентерології 16 міської лікарні.

17.03.16 р. проведено рентгенологічне обстеження. Шлунок оперований з накладанням ГЕА, видно вузьку смужку контрасту, яка йде в передню черевну стінку. Через 30 хв у шлунку сліди контрасту, в місці анастомозу видніється дно барієвої рідини «ніша». Заповнена тонка кишка. Заключення: хвороба оперованого шлунка; виразка ГЕА з утворенням нориці.

3 05.04.16 до 13.04.16 р. хворий проходив лікування в хірургічному відділенні 16 міської лікарні, після погодження з обласним хірургом проф. Березницьким Я. С. хворого переведено для операційного лікування в м. Дніпропетровськ у 6-ту міську клінічну лікарню. 19.04.16 р. виконано резекцію шлунка з ГЕА за Ру та двосторонню стовбурову ваготомію. Післяопераційний перебіг задовільний.

03.05.16 р. хворого госпіталізовано у відділення шлунково-кишкових кровотеч 16 міської лікарні м. Кривий Ріг з клінікою шлункової кровотечі: АТ 150/90 мм рт. ст., Р - 96 на хвилину, Ер $3,2 \times 10^{9}$, Нв - 96 г/л.

04.05.16 р. ФГДС: Ерозивний езофагіт, недостатність кардії 3 ст. Резикований шлунок. Ерозивний анастомазит, гострі виразки ГЕА, ускладнені кровотечею F - IIc.

Проведено гемостатичну терапію, гемотрансфузію еритроцитарної маси 500 мл, свіжозаморожену плазму 700 мл, пантапразол, рантак. 16.05.2016p. виписаний у задовільному стані.

З 10.06 до 17.06.2016 р. хворий знову проходив лікування в 16 міській лікарні у відділенні шлунково-кишкових кровотеч з кровотечею середнього ступеня тяжкості: АТ 110/60 мм рт. ст., Р - 80 на хвилину, Ер. - 3,7 х 109 , Нв - 116 г/л.

10.06.16 р. ФГДС: пептичні виразки ГЕА, кровотеча, що відбулася, F -III. Гемостатична терапія без гемотрансфузії.

Через 12 днів хворого госпіталізовано в хірургічне відділення 16 міської лікарні, де перебував з 29.06. до 14.07.2016 р. з кровотечею з пептичної виразки ГЕА за Ру. Виписаний у стабільному стані з задовільними показниками, з рекомендацією подальшого нагляду у гастроентеролога.

До грудня 2016 р. почувався задовільно, призначено II групу інвалідності, не працює.

На початку грудня з'явилося затримання проходження їжі по стравоходу, яке мало прогресуючий характер, стала проходити тільки вода, помітно почав худнути, зі слів хворого до 20 кг зменшилася вага за останні 1,5-2 місяці. Звернувся за консультацією до професора Десятерика В. I. шпиталізований в торакальне відділення 2-ї міської клінічної лікарні.

03.01.2017 р.: історія хвороби У-79 - діагноз стриктура нижньої третини стравоходу на тлі хвороби оперованого шлунка.

ФГДС 04.01.2017 р. : вхід в стравохід щілиноподібний, вільний. Просвіт помірно розширений, слизова рожева, далі 30 см, набрякла, пухка, покрита фібрином, на відстані 35-36 см просвіт створює звуження до 0,5 см, пройти апаратом неможливо, тканини кровоточать. За цитологічним дослідженням клітин пухлини не виявлено.

05.01.2017 р. проведено ренгеноскопію: після 2-х ковтків барієвої суспензії стравохід у середній третині розширений, в місці переходу в нижню третину звуження, контраст в шлунок не потрапляє. Заключення: декомпенсований стеноз нижньої третини стравоходу.

06.01.2017 р. виконано бужування бужами № 20 і 32 по черзі. Завдяки цьому вдалось провести фіброскоп в шлунок, у нижній третині шлунка гастроентероанастомоз, на передній стінці якого овальний дефект 3,5 х 2 м, покритий фібрином, дно щільне, анастомоз прохідний.

12.01.2017 р. проведено бужування нижньої третини стравоходу бужом № 40, кровотеча мінімальна, фіброскоп вільно проходить у шлунок.

17.01.2017 р. у задовільному стані хворого виписали з рекомендацією подальшого нагляду в гастроентеролога. 
20.04.17 р. хворий був демонстрований на засіданні міської асоціації хірургів м. Кривий Ріг. Самопочуття задовільне, їжу приймає вільно, маса тіла збільшилася на 8 кг. Больові прояви не спостерігає.

\section{СПИСОК ЛІТЕРАТУРИ}

1. Перфорация пептической язвы: нестандартные ситуации и нестандартные решения / С. Г. Белов / / Клінічна хірургія. 2016. - № 3. - 69-72.

2. Фармакоекономічна оцінка альтернативних методів лікування виразкової хвороби шлунка / І. Я. Дзюбановський // Шпитальна хірургія. - 2015. - № 3. - С. 5-8.

\section{REFERENCES}

1. Belov, S.G. (2016). Perforatsyya pepticheskoy yazvy: nestandartnye situatsii i nestandartnye resheniya [Peptic ulcer perforation: non-standard situations and nonstandard solutions]. Klin. Khirurhiia - Clinical Surgery, 3, 69-72 [in Russian].

2. Dziubanovskyi, I.Ya. (2015). Farmakoekonomichna otsinka alternatyvnykh metodiv likuvannia vyrazkovoi khvoroby shlunka [Pharmacoeconomic evaluation of alternative methods of treatment of peptic ulcer]. Shpytalna khirurhiia - Hospital Surgery, (3), 5-8 [in Ukrainian].
Після обговорення на засіданні асоціації хірургів прийнято рішення запропонувати хворому планове противиразкове лікування в відділенні гастроентерології та провести обстеження на наявність синдрому Золлінгера-Еллісона.

3. Прогнозування малігнізації та гострих ускладнень виразкової хвороби з застосуванням багатопараметричної нейромережевої кластеризації / І. Я. Дзюбановський // Клінічна хірургія. - 2015. - № 3. - С. 13-14.

4. Хирургическое лечение осложненной гастродуоденальной язвы / В. И. Лупальцов // Клінічна хірургія. - 2016. - № 3. - C. 16-19.

3. Dziubanovskyi, I.Ya. (2015). Prohnozuvannia malihnizatsii ta hostrykh uskladnen vyrazkovoi khvoroby z zastosuvanniam bahatoparametrychnoi neiromerezhevoi klasterysatsii [Predicting malignancy and acute complications of peptic ulcer using multiparameter neuro clustering]. Klin. Khirurhiia - Clinical Surgery, (3), 13-14.

4. Lupaltsov, V.I. (2016). Khirurgicheskoe lechenie oslozhnennoy gastroduodenalnoy yazvy [Surgical treatment of complicated gastroduodenal ulcer]. Klin. Khirurhiia - Clinical Surgery, (3), 16-19 [in Russian].

Отримано 20.04.2017

\title{
V. I. DESIATERYK, V. H. DORONYN, O. V. BURYK, A. A. ASKEROV, L. P. AHEENKO, V. M. MIROSHNYCHENKO
}

Dnipropetrovsk Medical Academy

Kryvyi Rih City Clinical Hospital № 2 of Dnipropetrovsk Regional Counsil

Kryvyi Rih City Clinical Hospital № 7 of Dnipropetrovsk Regional Counsil

Kryvyi Rih City Clinical Hospital № 8 of Dnipropetrovsk Regional Counsil

Kryvyi Rih City Clinical Hospital № 16 of Dnipropetrovsk Regional Counsil

\section{THE CASE OF SUCCESSFUL CONSERVATIVE TREATMENT OF GASTRIC FISTULA AS ONE OF THE MANY COMPLICATIONS OF DUODENAL ULCER}

\begin{abstract}
The publication is based on the clinical examination of the patient M. during last six years. In 201046 years old patient was sent to the Center of acute pancreatitis with the diagnosis of severe acute pancreatitis. The patient was operated after 12 hours of the admission on the perforated duodenal ulcer with widespread peritonitis against the background of ulcerative stenosis of the duodenum. Suturing ulcers with superposition of anterior gastroenteroanastomosis was perfomed. Systematic treatment was not recieved. In February 2016, he entered the surgical department with a phlegmon of the anterior abdominal wall, the case of which was the penetrarion of ulcers of gastroenteroanastomosis into the anterior abdominal wall. By opening the phlegmon a gastric fistula was opened, which was closed against a background of intensive anti-inflammatory therapy and the use of large doses of pentacrasole.

In April 2016 the operation of resection of the stomac and Roux gastroenteroanastomosis were perfomed. Later the patient suffered three episodes of bleeding, they were stoped conservatively.

At the end of 2016 there were difficulties in swallowing food, stenosis in the oesophagus was diagnosed. It was treated in the thoracic department using bouginage and permeability was restored. Inspection in April 2017 - the patient has satisfactory condition, swallowing is free. At the FGD in the field of gastroenteroanastomosis recurrent ulcer was found.

The patient was offered hospital treatment in the department of gastroenterology and the examination for Zollinger-Ellison syndrome.
\end{abstract}

Key words: complicated peptic ulcer; gastric fistula; conservative treatment. 
В. И. ДЕСЯТЕРИК, В. Г. ДОРОНИН, А. В. БУРИК, А. А. АСКЕРОВ, И. С. СТАРОДУБЦЕВ, Л. П. АГЕЕНКО, В. Н. МИРОШНИЧЕНКО

Днепропетровская медицинская академия МЗ Украины

Криворожская городская клиническая больница № 2 Днепропетровского областного совета

Криворожская городская больница № 7 Днепропетровского областного совета

Криворожская городская клиническая больница № 8 Днепропетровского областного совета

Криворожская городская больница № 16 Днепропетровского областного совета

\section{С.УУЧЙ УСПЕШНОГО КОНСЕРВАТИВНОГО ЛЕЧЕНИЯ ЖЕЛУДОЧНОГО СВИША КАК ОДНОГО ИЗ МНОГИХ ОС.ЛОЖНЕНИЙ ЯЗВЕННОЙ БОЛЕЗНИ ДВЕНАДЦАТИПЕРСТНОЙ КИШКИ}

В публикации приведено клиническое наблюдение одного пациента М. в течение последних шести лет. В 2010 г. пациент М., 46 лет был направлен в центр острого панкреатита с предположительным диагнозом острый тяжелый панкреатит, а через 12 ч после поступлення прооперирован по поводу перфоративной язвы двенадцатиперстной кишки с распространенным перитонитом на фоне язвенного стеноза двенадцатиперстной кишки. Выполнено ушивание язвы с наложением впередиободочного гастроэнтероанастомоза. Систематического лечения не получал. В феврале 2016 г. поступил в хирургическое отделение с флегмоной передней брюшной стенки, причиной которой была пенетрация язвы гастроэнтероанастомоза в переднюю брюшную стенку. После вскрытия флегмоны открылся желудочный свищ, который закрылся на фоне интенсивной противовоспалительной терапии и применением больших доз пантапразола.

В апреле месяце 2016 г. проведена резекция желудка и гастроэнтероанастомоз по Ру. В последующем перенес три эпизода кровотечений, которые купировали консервативно.

В конце 2016 г. появились затруднения при глотании пищи, диагностирован стеноз нижней части пищевода, лечился в торакальном отделении посредством бужированиия, проходимость восстановлена. Повторно осмотрен в апреле 2017 г., состояние удовлетворительное, глотание свободное. На ФГДС в области гастроэнтероанастомоза рецидивная язва.

Больному предложено стационарное лечение в отделении гастроэнтерологии и обследование на предмет синдрома ЗоллингераЭллисона.

Ключевые слова: осложненная язвенная болезнь; сумочный свищ; консервативное лечение. 